\title{
Synthesis and implication of grafted polymeric adsorbent for heavy metal removal
}

\author{
Md. Owaleur Rahman ${ }^{1}$. Nazia Rahman² · G. M. Foysal Ahmed ${ }^{1}$ Md. Sajid Hasan ${ }^{1}$ Nirmal Chandra Dafader ${ }^{2}$. \\ Md. Jahangir Alam ${ }^{1}$ (i) Shahnaz Sultana ${ }^{2} \cdot$ Farah Tasneem Ahmed ${ }^{2}$
}

Received: 20 February 2020 / Accepted: 13 May 2020 / Published online: 16 May 2020

(c) Springer Nature Switzerland AG 2020

\begin{abstract}
Nowadays, grafted polymeric composite has received much attention as an alternative adsorbent of heavy metal removal. The grafted polymeric adsorbent (GPA) in the form of composite was prepared using diallyl dimethyl ammonium chloride (DADMAC) and acrylic acid embedded nonwoven irradiated polythene sheet. The prepared GPA was characterized using Fourier transform infra-red (FTIR), scanning electron microscopy (SEM), and thermogravimetric analysis to understand molecular interaction, surface morphology and physical phenomena of them. The effect of parameters including $\mathrm{pH}$, initial metal concentration, contact time, as well as temperature on the adsorption of $\mathrm{Cu}(\mathrm{II}) / \mathrm{Cr}(\mathrm{VI})$ was studied sequentially. The result shows that the GPA had utmost grafting yield of $192 \%$ with reaction time $4.0 \mathrm{~h}$ at $50 \mathrm{kGy}$. The maximum adsorption was found up to $153.89 \mathrm{mg} \mathrm{Cu} / \mathrm{g}$ and $17.34 \mathrm{mg} \mathrm{Cr} / \mathrm{g}$ with an initial concentration of $1000 \mathrm{ppm}$, a contact time of $24 \mathrm{~h}, \mathrm{pH}$ of $4.84[\mathrm{Cu}(\mathrm{II})]$, and $1.5[\mathrm{Cr}(\mathrm{VI})]$ at room temperature $\left(25^{\circ} \mathrm{C}\right)$ indicating superb synergetic adsorption capacity of the GPA. Comparing the Langmuir and Freundlich adsorption isotherm models, the former fitted well with $\mathrm{Cr}$ and latter with $\mathrm{Cu}$ adsorption data implying that the models can be applied to uptake $\mathrm{Cu}(\mathrm{II}) / \mathrm{Cr}(\mathrm{VI})$ by $\mathrm{GPA}$. In the kinetic adsorption experiment, adsorbed metal almost reached equilibrium about $10 \mathrm{~h}$ for the GPA and followed the pseudo-second-order kinetic model. Thus, the GPAs are propriety and competent in terms of capability and reusability to remove heavy metal ions.
\end{abstract}

Keywords DADMAC · Acrylic acid · Irradiated polythene sheet $\cdot$ GPA $\cdot$ Heavy metals

\section{Introduction}

Copper and Chromium are the lethal heavy metal pollutants extensively used in different industries [1]. Anthropogenic activities are the major sources of $\mathrm{Cu} / \mathrm{Cr}$, for instance, sewage treatment processes, brass manufacturing, petroleum refining, electroplating smelting, mining, coal-fired power stations, metal production, earth's crust, waste incinerators, leather tanning, paint processing, wood preservation and from the application of agricultural chemicals [2, 3]. The two stable oxidation states of Chromium in aqueous environments are trivalent Chromium ( $\mathrm{Cr}(\mathrm{III}))$ and hexavalent chromium ( $\mathrm{Cr}(\mathrm{VI}))$ with different toxicities, mobilities, and bioavailabilities. In general, $\operatorname{Cr}(\mathrm{III})$ is relatively less toxic than $\operatorname{Cr}(\mathrm{VI})[4,5]$. Although Copper and Chromium are the fundamental micro-nutrients required by living organisms, beyond their allowable level of $\mathrm{Cu}(\mathrm{II})$ and $\mathrm{Cr}(\mathrm{VI})$ can make significant changes on human health such as chest pains, vomiting anemia, hypoglycemia, and irritation of the eyes, skin, and nose, stomach intestinal distress pallor, hypoglycemia, stomach abdominal pain, even kidney

$\triangle$ Md. Jahangir Alam, jahangirche@gmail.com | 'Department of Chemical Engineering, Jashore University of Science and Technology, Jashore 7408, Bangladesh. ${ }^{2}$ Nuclear and Radiation Chemistry Division, Institute of Nuclear Science and Technology, Atomic Energy Research Establishment, Savar, Dhaka 1349, Bangladesh. 
damage, eardrum perforation, lung carcinoma and eventual death [6-10]. Therefore, the effective methods to remove $\mathrm{Cu}(\mathrm{II})$ and $\mathrm{Cr}(\mathrm{VI})$ from polluted water and soil are desperately needed. To remove heavy metals from the aqueous phase many techniques have been explored, including electrochemical deposition [11], ion-exchange [12], coagulation, and precipitation [13], solidification $[14,15]$, membrane separation technology [16], and adsorption. Recently, promising technology adsorption is used for the removal of $\mathrm{Cu}(\mathrm{II})$ and $\mathrm{Cr}(\mathrm{VI})$ owing to easy operation, high efficiency, relatively low-cost, and insensitivity to toxic substances [17-22].

Several low-cost adsorbents such as sugarcane bagasse, rice husk, sawdust, coconut husk, oil palm shell, neem bark, etc., have been used for the removal purpose of heavy metals from wastewater [23-29]. Nevertheless, the efficiency usually not as efficient as radiation grafted polymers to remove heavy metals. The radiation method is a clean and effective technology to produce grafted polymeric adsorbent (GPA) [30]. 'Grafting' is a method where monomers are covalently bonded onto the polymer chains [31]. The desired property of adsorbent with proper mechanical strength can be obtained by this method, without using any harmful poisonous initiator $[32,33]$. Available methods of radiation polymerization involve direct irradiation of fiber in monomer solution, vapor phase irradiation method, and pre-irradiation.[30]. Different authors have intensively studied the grafting of acrylic acid onto nonwoven polyethylene (PE) film and some of their attention on the effect of amphoteric properties of obtained grafted nonwoven PE films. Non-woven polyethylene is a low-cost material used for different purposes. Grafting of diallyl dimethyl ammonium chloride (DADMAC)/Acrylic acid (AAc) onto inert polymeric supports (e.g., polyethylene) will make it a better quality of adsorbent with good mechanical strength. The grafting process of DADMAC/AAC is very important in improving the adsorption properties of gamma-ray induced polymeric materials for the removal of heavy metal ions from aqueous solution. The present work has explored a new adsorbent by grafting of binary monomers acrylic acid and DADMAC on nonwoven irradiated polythene sheets. Then the prepared GPA was characterized using Fourier Transform Infra-Red (FTIR), Scanning Electron Microscopy (SEM), and Thermogravimetric Analysis (TGA) to understand molecular interaction, surface morphology and physical phenomena of them. The prepared GPA had strengthened mechanical properties due to increased crosslinking of it. The parameters influencing the adsorption process were optimized including reaction time, $\mathrm{pH}$, initial concentration as well as temperature on the adsorption of $\mathrm{Cu}(\mathrm{II}) /$ $\mathrm{Cr}(\mathrm{VI})$. Therefore, the synthesized GPA was implicated in the removal of copper and chromium ions to understand the adsorption potential of the polymeric composite using radiation.

\section{Materials and methods}

\subsection{Materials}

Nonwoven Polyethylene, AAc (purity 98.5\%), and DADMAC $65 \%$ in water were procured from Kurashiki MFG Co. Ltd; Guangdong, 515,021, China; and Fluka Chemie AG CH-9470 Buchs, respectively. Copper Sulfate and Potassium Dichromate salt were purchased from E. Merck Darmstadt, Germany, and Techno Pharmachem, India, respectively. Hydrochloric acid (purity $37 \%$ ), acetone (purity 99.5\%) were collected from Merck KGaA 64,271 Darmstadt, Germany. Sodium hydroxide was received from Merck Limited, Mumbai.

\subsection{Instruments}

Electrical Balance (Model AR 1140, supplied by SMH Engineering and Trading Co., Dhaka, Bangladesh.), Gravity convention oven (supplied by Memmert UM series, temperature range $30-220^{\circ} \mathrm{C}$.), Vial, pH Meter (Model: Cole-Parmer-5991-81 FIB-12, supplied by Institute of Electronics, AERE, Dhaka, Bangladesh.), Volumetric flasks (25, 50, 100 and $500 \mathrm{~mL}$ ), Test tube, Beaker, crucible, Micro Pipettes, Filter paper (Whatman Grade 42 ashless quantitative filter papers), Funnel, Filtration stand, Digital Caliper (Dimensions of PE films were measured in digital caliper.), Water Bath, Atomic Absorption Spectrophotometer (Model: Atomic Absorption Spectrophotometer was AA-6800 and supplied by SHIMADZU, Japan), Cobalt -60 radiation, Gamma radiation source, (Model: GSCIE -11), FT-IR Spectrophotometer (Model: AIM-8800, supplied by SHIMADZU, Japan.) were used in this study.

\subsection{Preparation of grafted polymeric adsorbent}

Non-woven polyethylene sheets (thickness $0.04 \mathrm{~mm}$ ) were collected from Kurashiki MFG Co. Ltd. The sheets were cut into small pieces of $10 \mathrm{~cm}$ length and $1.5 \mathrm{~cm}$ width and then taken 6 pieces to do this experiment. Then the pieces were marked as 1 to 6 and put them in a packet. The non-woven PE films were irradiated using the Co-60 gamma radiation source at $50 \mathrm{kGy}$ radiation dose at ambient temperature. The irradiated PE films were preserved at dry-ice condition until further use. The monomer solution was prepared by the addition of $20 \mathrm{~g}$ DADMAC and $20 \mathrm{~g} \mathrm{AAc}$ to $110 \mathrm{~mL}$ distilled water. The monomers and distilled water were taken in a beaker, heated $70^{\circ} \mathrm{C}$ on a hot plate for half an hour to make a clear solution. Then 
the solution was placed in the gas passing bottle. Argon gas was passed for one hour. The monomer solution was bubbled with argon gas for the removal of dissolved oxygen. The 6 pieces of previously irradiated nonwoven PE films were taken in a tube and immediately $70-75 \mathrm{~mL}$ of the deaerated monomer solution were poured into the tube. After filling the tube with monomer solution, it was closed with a lid for avoiding intrusion of oxygen from the air into the monomer solution. Next, the grafting reaction was carried out at $80^{\circ} \mathrm{C}$ for $4 \mathrm{~h}$ in a water bath. The GPA had utmost grafting yield of $192 \%$ with reaction time $4.0 \mathrm{~h}$ at $50 \mathrm{kGy}$. Then the grafted non-woven PE film was appropriately washed. After washing and drying, it will be ready to use in the experiment.

\subsection{Preparation of copper ions solution}

$1.97 \mathrm{~g} \mathrm{CuSO}_{4} \cdot 5 \mathrm{H}_{2} \mathrm{O}$ was weighted in digital balance and took in a $500 \mathrm{~mL}$ volumetric flask. Then the flask was filled with distilled water up to the mark. Thus $1000 \mathrm{ppm}$ of $\mathrm{Cu}$ (II) ion solution was prepared. Then $0.5 \mathrm{ppm}, 1 \mathrm{ppm}, 3 \mathrm{ppm}$, $5 \mathrm{ppm}, 10 \mathrm{ppm}$, and $15 \mathrm{ppm}$ were made from the stock solution of $\mathrm{Cu}(\mathrm{II})$. On the other hand, $1.41 \mathrm{~g}$ of $\mathrm{K}_{2} \mathrm{Cr}_{2} \mathrm{O}_{7}$ was weighted and took in a $500 \mathrm{~mL}$ volumetric flask. Then the flask was filled with distilled water and prepared $1000 \mathrm{ppm}$ of $\mathrm{Cr}(\mathrm{Vl})$ ion solution. Then $0.05 \mathrm{ppm}, 0.1 \mathrm{ppm}, 0.5 \mathrm{ppm}$, $1 \mathrm{ppm}, 3 \mathrm{ppm}, 5 \mathrm{ppm}, 10 \mathrm{ppm}$, and $15 \mathrm{ppm}$ solutions were prepared from the stock solution of $\mathrm{Cr}(\mathrm{VI})$. The prepared solutions were reserved at room temperature before testing and used to make the standard calibration curve in Atomic Absorption Spectrophotometer.

\subsection{Sample preparation for AAS}

The vials were used to take $25 \mathrm{~mL}$ copper/chromium ion solution to prepare sample for AAS analysis. A piece of grafted non-woven PE film was put into the metal ion solution in which initial concentration was known. After keeping the prepared adsorbent in desired conditions for a definite time, the solution was taken for AAS analysis to measure the final concentration of the solution. The physical appearance of grafted films were shown in Fig. 1, after adsorption of $\mathrm{Cu}(\mathrm{II})$ and $\mathrm{Cr}(\mathrm{VI})$ ions.

\subsection{Determination of adsorption capacity of metal ions}

Atomic Absorption Spectrometry (AAS) is a prevalent and reliable technique for detecting metals and metalloids in environmental samples. The total metal content in solution and GPA samples was measured by Atomic Absorption Spectrometry. At first, a typical set of standard calibration curves with good linear regression and better relative standard deviations were attained. The adsorption was explored by adding a weight piece of GPA into $25 \mathrm{ml}$ of $1000 \mathrm{ppm}$ metal solution $(\mathrm{pH} 4.84(\mathrm{Cu})$ and $1.5(\mathrm{Cr}))$ at room temperature $\left(27^{\circ} \mathrm{C}\right)$ for the study of adsorption kinetics. In contrast, for the study of adsorption isotherms the adsorption was explored by adding a weight piece of GPA into $25 \mathrm{ml}$ of different concentration (200-1000 ppm) of metal solution (pH $4.84(\mathrm{Cu})$ and $1.5(\mathrm{Cr}))$ at room temperature $\left(27^{\circ} \mathrm{C}\right)$. On completion of adsorption, the spectrophotometry was used to determine metal ions content in the resultant of sample. The metal adsorption capacity was calculated according to the following Eq. 1.

Metal adsorption capacity $=\left(V\left(C_{0}-C_{e}\right)\right) / W$

where, $\mathrm{V}=$ Volume of the $\mathrm{Cu}(\mathrm{II}) / \mathrm{Cr}(\mathrm{VI})$ solution in $\mathrm{L}_{\text {; }}$ $\mathrm{W}=$ Weight of GPA in $\mathrm{g} ; \mathrm{C}_{0}=$ Initial concentration $(\mathrm{mg} / \mathrm{L})$ of $\mathrm{Cu}(\mathrm{II}) / \mathrm{Cr}(\mathrm{VI})$ in ppm before adsorption; $\mathrm{C}_{\mathrm{e}}=$ Concentration $(\mathrm{mg} / \mathrm{L})$ of $\mathrm{Cu}(\mathrm{II}) / \mathrm{Cr}(\mathrm{Vl})$ in equilibrium.

\section{Results and discussions}

\subsection{Characterization of PE and GPA}

The FTIR analysis was explored to identify the embedded compounds DADMAC and acrylic acid (AAC) on PE sheet.
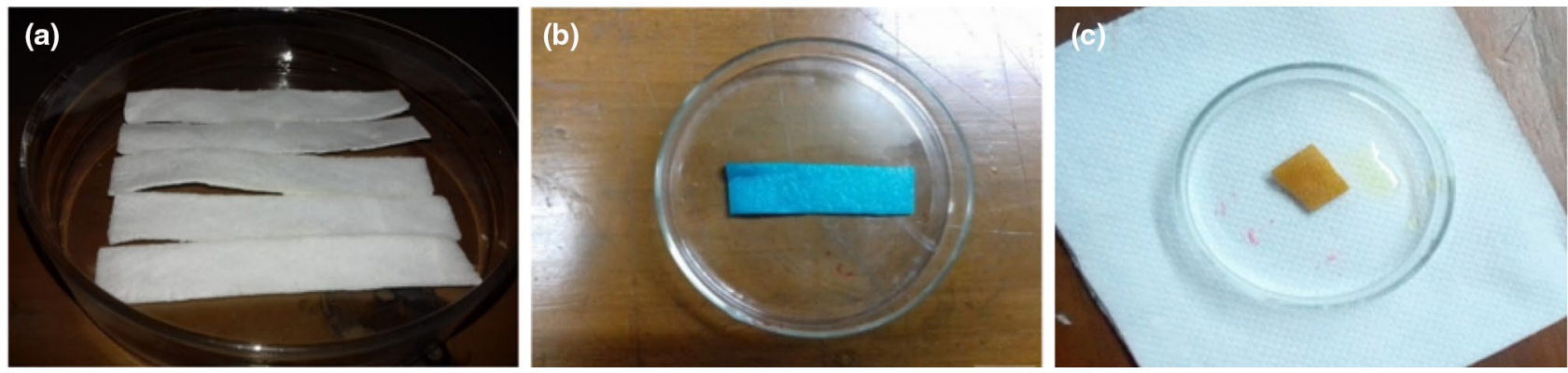

Fig. 1 Grafted filma before,b after $\mathrm{Cu}(\mathrm{II}), \mathbf{b}$ after $\mathrm{Cr}(\mathrm{VI})$ adsorption 
Grafting of DADMAC/acrylic acid (AAC) was introduced on pre-irradiated $P E$ films using $\gamma$ radiation. Figure 2 shows the FTIR spectrum of films PE and PE-AAc-DADMAC. The FTIR pattern of PE showed the main characteristic peaks at about 2911 , and $2845 \mathrm{~cm}^{-1}$ is assigned to C-H asymmetric and symmetric stretch from methylene groups, respectively. Another absorbance bands can be observed at $1464 \mathrm{~cm}^{-1}$ associated with $\mathrm{C}-\mathrm{H}$ bending vibration and $720 \mathrm{~cm}^{-1}$ associated with $\mathrm{C}-\mathrm{C}$ rocking vibration. On the other hand, Fig. 2. also exhibits peak observed at $1721 \mathrm{~cm}^{-1}$ peak to carbonyl bond of AAc and other peaks at $1449 \mathrm{~cm}^{-1}$ and $2924 \mathrm{~cm}^{-1}$; those are the fundamental frequency for $\mathrm{CH}_{3}$ and $\mathrm{CH}_{2}$ bending vibrations of DADMAC. Therefore, the above analysis confirms the addition of DADMAC and AAC on the PE sheet. In literature, Ali said (2005) [34] reported that a peak was assigned at $1720 \mathrm{~cm}^{-1}$ for the carbonyl bond of AAc and Kwak et al. (2016) [35] and Pirgalıoglu et al. (2015) [36] found $\mathrm{CH}_{3}$

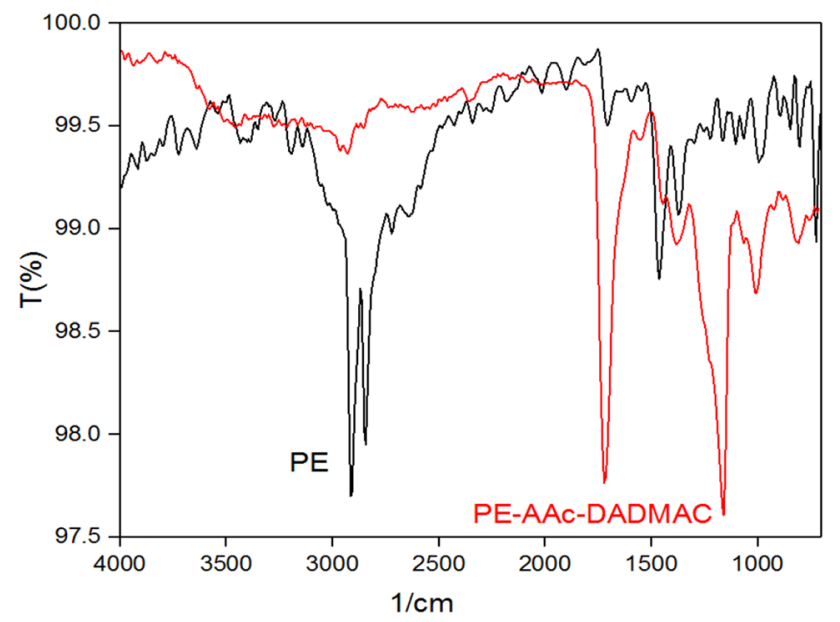

Fig. 2 FTIR Result of PE and PE-AAc-DADMAC
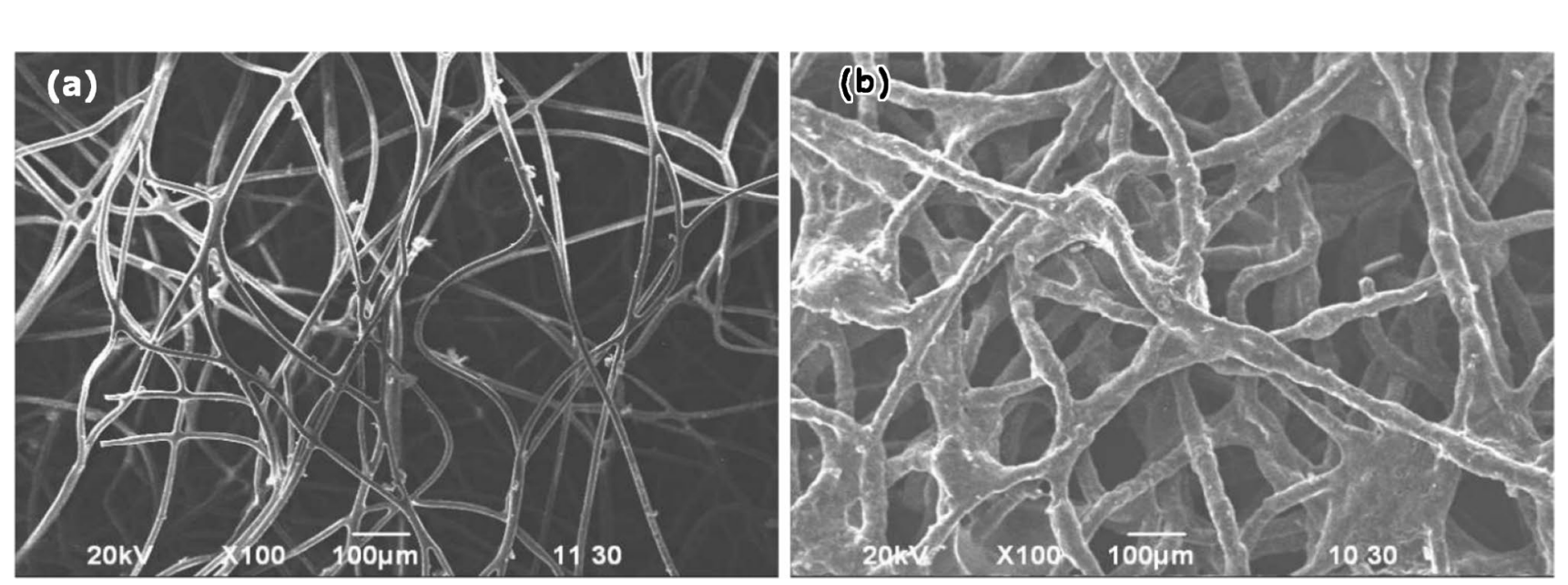

and $\mathrm{CH}_{2}$ bending vibrations of DADMAC at $1474 \mathrm{~cm}^{-1}$ and $2900 \mathrm{~cm}^{-1}$.

Figure $3 a$ and $b$ show the Scanning Electron Microscopy images of nonwoven PE and PE-AAc-DADMAC to compare the physical appearance, respectively. The surface morphology of bared PE film shows a normal or regular shape and diameter of fibers. On the other hands, the SEM image of AAc/DADMAC onto nonwoven PE displays a significant change in shape and also a slight increase in the average diameter of fibers that offer additional physical shreds of evidence of the grafting compare to bare PE films.

The thermal stability and decomposition pattern of PE and PE-AAc-DADMAC films were investigated by the thermogravimetric analysis (TGA) and presented clear differences of the thermal stability of them in Fig. 4. TGA of PE showed a one-stage characteristic thermogram. It exhibits thermally stable up to temperature $220^{\circ} \mathrm{C}$. A resilient

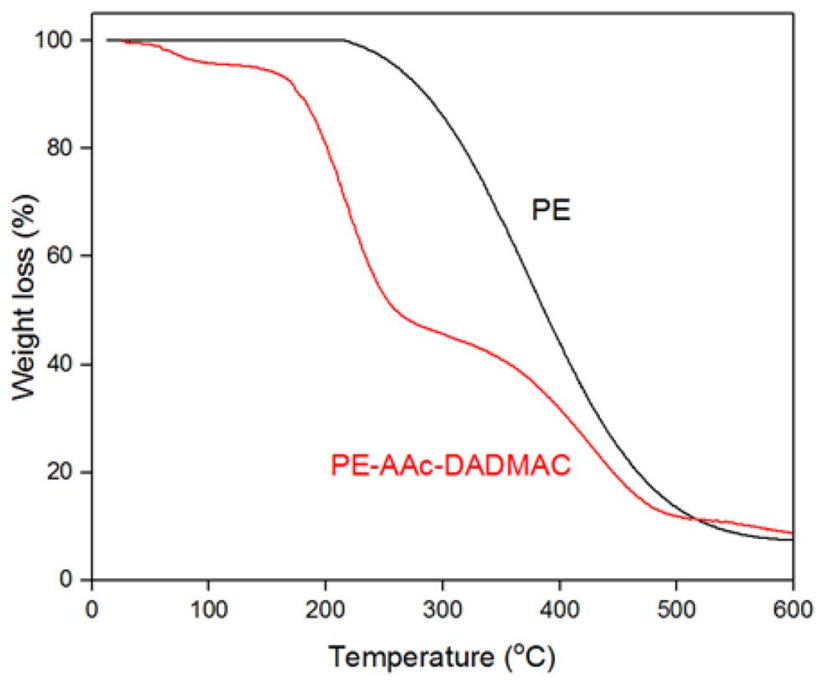

Fig. 4 TGA Results of PE and PE-AAC-DADMAC samples

Fig. 3 SEM image of a PE,b PE-AAC-DADMAC

SN Applied Sciences

A SPRINGER NATURE journal 
weight loss of above $90 \%$ was observed of PE films owing to the decompose of PE backbone over $220^{\circ} \mathrm{C}$ to around $600{ }^{\circ} \mathrm{C}$. On the other hand, four decomposition stages appeared for PE-AAc-DADMAC film in TGA analysis. At temperature steps $75-120^{\circ} \mathrm{C}, 200-365^{\circ} \mathrm{C}, 400-479{ }^{\circ} \mathrm{C}$, and above $479{ }^{\circ} \mathrm{C}$; followed the order of weight loss $5.5 \%$ shows lower $\mathrm{H}_{2} \mathrm{O}$ content in the grafted sample, $62 \%$ may be due to decomposition of PE and functional group DADMAC, $87 \%$ and above $90 \%$ weight loss indicating the decomposition of the grafted polymer backbone, respectively. The TGA curves confirms the lower thermal stability of PE-AAC-DADMAC when compared to PE may be attributed to the low thermal stability of DADMAC.

\subsection{Adsorption capability of the synthesized composite films for $\mathrm{Cu}(\mathrm{II}) / \mathrm{Cr}(\mathrm{VI})$}

Figure 5 shows the adsorption capacity of prepared composite grafted film from AAc, DADMAC on PE sheet with $\mathrm{pH} 1$ to 5.3. It shows that the $\mathrm{pH}$ effect on $\mathrm{Cu} / \mathrm{Cr}$ adsorption by PE-AAc-DADMAC film was significant. The $\mathrm{pH}$ value from 1 to 4.84, the adsorption ability of the GPA enhanced with $\mathrm{pH}$. Nevertheless, the adsorption capacity of GPA declined when the $\mathrm{pH}$ range above 4.84 may be owing to solubility loss of adsorbent for $\mathrm{Cu}(\mathrm{II})$. On the other hand, the adsorption capacity of $\mathrm{Cr}(\mathrm{VI})$ was utmost at $\mathrm{pH} 1.5$ and beyond this, the capacity was decreased. Therefore, the removal capacity for $\mathrm{Cu} / \mathrm{Cr}$ of PE-AAc-DADMAC in acidic conditions was better as shown in Fig. 5 and was highest at $\mathrm{pH} 4.84(\mathrm{Cu})$ and $1.5(\mathrm{Cr})$. The best adsorption capacity was obtained $150.36 \mathrm{mg} . \mathrm{Cu} / \mathrm{g}$ and $17.34 \mathrm{mg} . \mathrm{Cr} / \mathrm{g}$ for $\mathrm{pH} 4.84$ and 1.5 respectively, and $1000 \mathrm{ppm}$ metal ion solution at room temperature. In literature, Yue et al. [37]

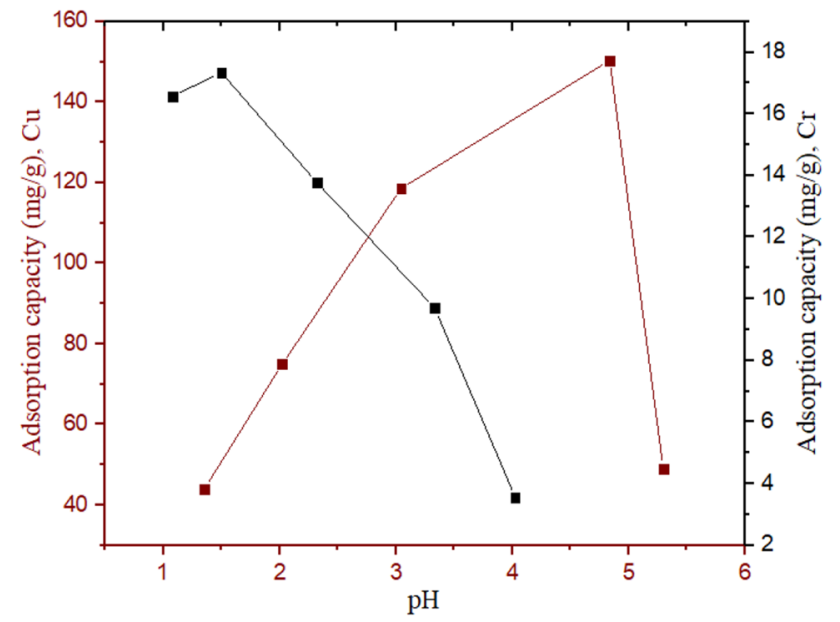

Fig. 5 Effect of the pH values on the adsorption capacities of GPA for $\mathrm{Cu} / \mathrm{Cr}$ removal also reported that the adsorption capacity of synthetized adsorbent was high in acidic medium to adsorb metal ions.

Different concentrations of $\mathrm{Cu}(\mathrm{II}) / \mathrm{Cr}(\mathrm{VI})$ solutions such as 200 to $1500 \mathrm{ppm}$ were prepared for adsorption ability checked that shown in Fig. 6 . The removal ability of the GPA for copper/chromium was enhanced with the increase of the initial concentration of the metal ion because of a high concentration gradient formed between $\mathrm{Cu} / \mathrm{Cr}$ solution and GPA surface. The adsorption capacity has achieved a plateau (153.89 mg.Cu/g and $17.34 \mathrm{mg} . \mathrm{Cr} / \mathrm{g}$ ) at $1000 \mathrm{ppm}$ of metal ion at $\mathrm{pH} 4.84(\mathrm{Cu})$ and $1.5(\mathrm{Cr})$ for contact time $24 \mathrm{~h}$ at room temperature. Moreover, a reduced amount of adsorption occurred when the concentration increased above $1000 \mathrm{ppm}$ due to almost filled up of active sites inside GPA. Similar trend was found in different published papers such as Yue et al. [37].

Figure 7 shows the effect of time on the adsorption capacities of CU (II) by the GPA. Here adsorption capacities increased rapidly with the increase of the time from 1.5 to $5 \mathrm{~h}$. Then the adsorption process becomes slow with the increase of time from 5 to $24 \mathrm{~h}$ until the equilibrium condition reached. The equilibrium adsorption capacity of GPA to uptake $\mathrm{Cu}$ (II) was $153.89 \mathrm{mg} . \mathrm{Cu} / \mathrm{g}$ and $17.34 \mathrm{mg} . \mathrm{Cr} / \mathrm{g}$ after $24 \mathrm{~h}$ with $\mathrm{pH} 4.84(\mathrm{Cu})$ and $1.5(\mathrm{Cr})$ at room temperature of 1000 ppm solution. Rahman et al. [38] reported that the adsorption equilibrium condition reached for metal ion removal on polymeric composite with contact time $72 \mathrm{~h}$.

The adsorption capacity concerning the applied temperature was shown in Fig. 8. The $\mathrm{Cu} / \mathrm{Cr}$ removal ability of GPA was enhanced with the increase in the applied temperature imply it was an endothermic process for GPA to adsorb $\mathrm{Cu} / \mathrm{Cr}$. In this study, we used the temperature range from $25^{\circ} \mathrm{C}$ to $80^{\circ} \mathrm{C}$ for $\mathrm{Cu} / \mathrm{Cr}$ adsorption. The utmost value

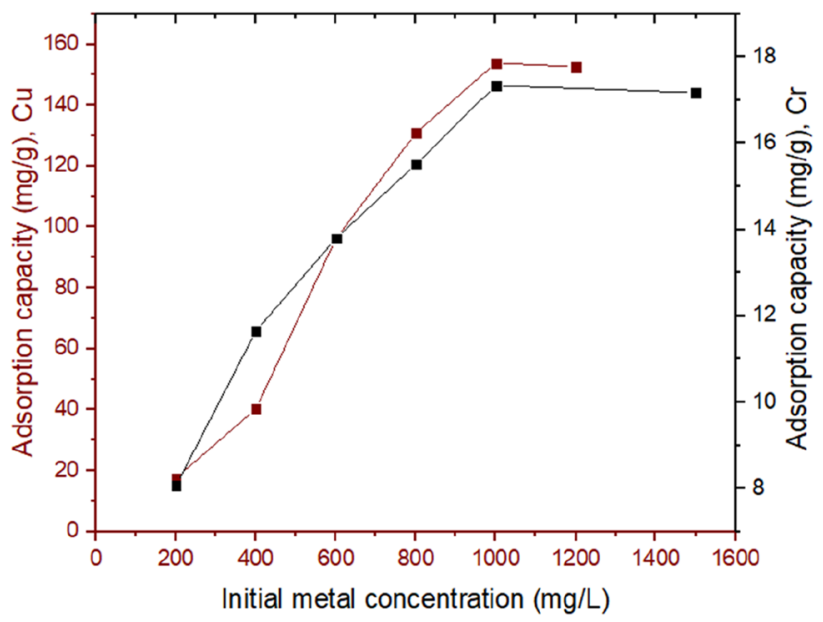

Fig. 6 Effect of the initial metal concentration on the adsorption capacities of GPA 


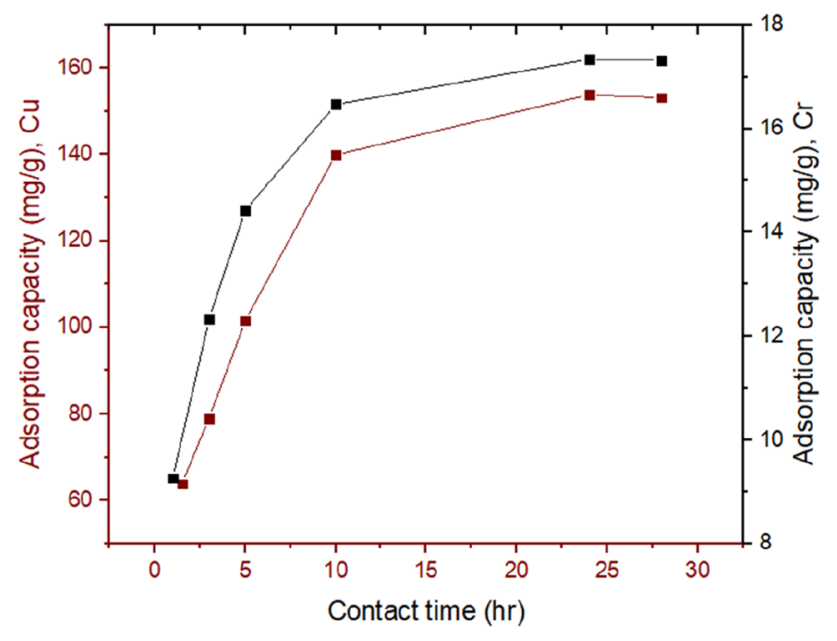

Fig. 7 Effect of contact time on adsorption capacity of GPA

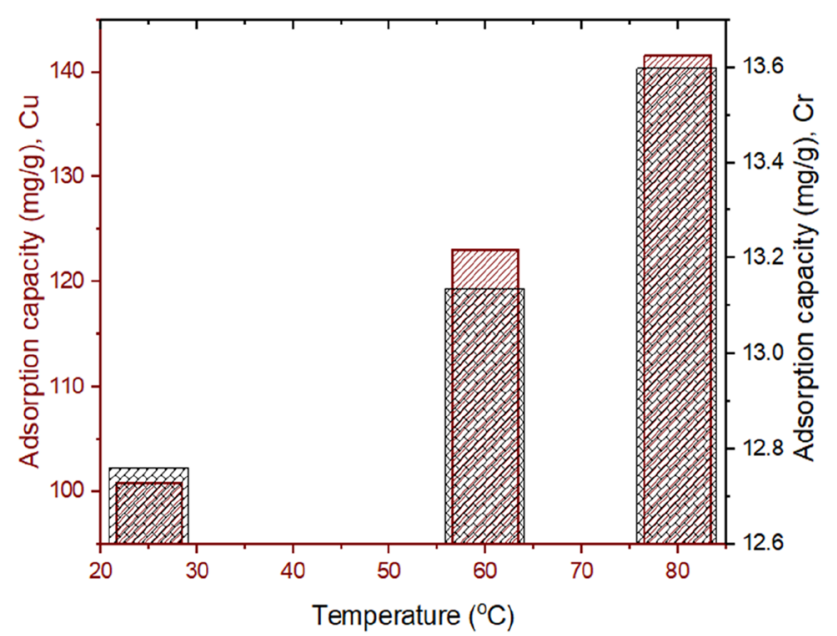

Fig. 8 Effect of the temperature on the adsorption capacities of GPA

of adsorption was $141.48 \mathrm{mg} . \mathrm{Cu} / \mathrm{g}$ and $13.60 \mathrm{mg} . \mathrm{Cr} / \mathrm{g}$ for $1000 \mathrm{ppm}$ initial metal concentration at $80^{\circ} \mathrm{C}$ with pH $4.84(\mathrm{Cu})$ and $1.5(\mathrm{Cr})$ for contact time $5 \mathrm{~h}$. The findings of this study closely agree with Yue et al. [37] and they used 1,6-hexanediamine modified magnetic chitosan as an adsorbent to remove metal ions. They observed the best adsorption capacity was achieved at $40^{\circ} \mathrm{C}$ of experimental range from $20^{\circ} \mathrm{C}$ to $40^{\circ} \mathrm{C}$.

\subsection{Adsorption isotherm models}

The experimental data from the process of adsorbing $\mathrm{Cu}(\mathrm{II}) / \mathrm{Cr}(\mathrm{VI})$ by using GPA were analyzed by Langmuir and Freundlich isotherms to get the relationship between the adsorbate on the surface of the GPA and adsorbate in the liquid phase. The former isotherms assume homogeneous process while the latter takes up a heterogeneous system that can be express as following Eqs. (2) and (3), respectively.

$\frac{C_{e}}{Q_{e}}=\frac{C_{e}}{Q_{\max }}+\frac{1}{Q_{\max } B}$

$\log Q_{e}=\log k+\frac{1}{n} \log C_{e}$

where $C_{e}(\mathrm{mg} / \mathrm{l})$ and $Q_{e}(\mathrm{mg} / \mathrm{g})$ represent the content and quantity of $\mathrm{Cu}(\mathrm{II}) / \mathrm{Cr}(\mathrm{VI})$ when the adsorption reaches equilibrium. The $B, k$, and $n$ indicate Langmuir factor $(1 / \mathrm{mg})$, Freundlich factors, and Adsorption intensity, respectively. Furthermore, $Q_{\max }(\mathrm{mg} / \mathrm{g})$ represents the maximal adsorption amount and exhibits negative value for $\mathrm{Cu}$ adsorption comply disagree with Langmuir isotherm. Nevertheless, results exhibit the adsorption data of $\mathrm{Cu}$ well fitted with Freundlich isotherm. The adsorption phenomena using obtain data were best fitted with Langmuir isotherm in case of $\mathrm{Cr}$ adsorption (with correlation coefficient $\mathrm{R}^{2}=0.99$ ) that present in Fig. 9. compared to Freundlich. The regression correlation coefficient and other factors value were listed in Table 1. Bankole et al. [40] have presented isotherm parameters on the adsorption of the selected heavy metals by P-CNTs and found negative isotherm parameters for few metals.

\subsection{Adsorption kinetic models}

The measured data of adsorption of $\mathrm{Cu}(\mathrm{II}) / \mathrm{Cr}(\mathrm{VI})$ ions on the GPA was modeled by two kinetic models as Pseudofirst order and Pseudo-second order and shown in Fig. 10. The correlation coefficients $\left(R^{2}\right)$ of these two kinetic models were evaluated and chosen one as the better fitted. In this study, a higher $R^{2}=0.99$ value was obtained for the Pseudo-second order kinetic studies that imply better description ability of adsorption kinetics. The Pseudo-first order and Pseudo-second order kinetic models were fitted using measured data by the following Eqs. (4) and (5), respectively.

$\log \left(Q_{e}-Q_{t}\right)=\log Q_{e}-\left(k_{1} / 2.303\right) t$

$\frac{t}{Q_{t}}=\frac{1}{k_{2} Q_{e}^{2}}+\frac{t}{Q_{e}}$

where $Q_{e}$ and $Q_{t}$ denote adsorption amount $(\mathrm{mg} / \mathrm{g})$ at equilibrium and time $t(\mathrm{~h})$, respectively. $k_{1}$ and $k_{2}$ indicate the first and second-order kinetic constants, respectively. The kinetic parameters and correlation coefficient $\left(R^{2}\right)$ were attained by linear fitting the experimental data listed in Table 1. Moreover, the overall process for adsorbing 

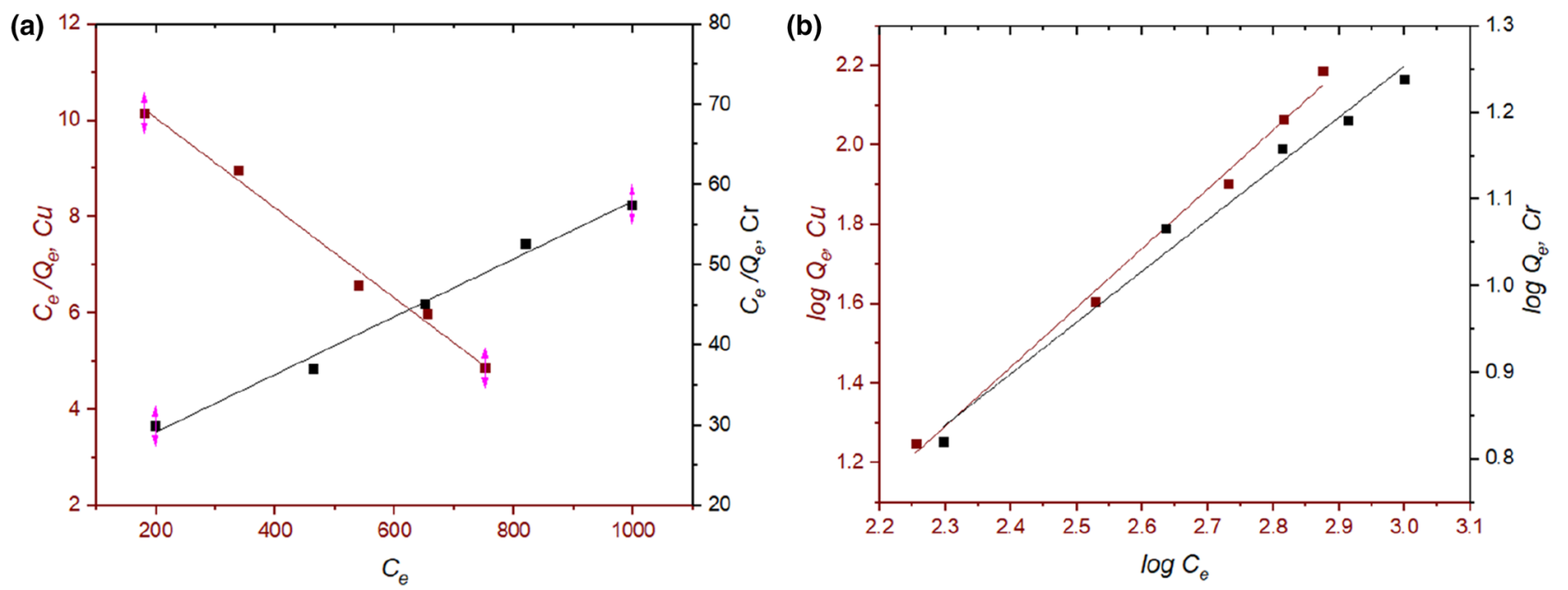

Fig. 9 Adsorption isotherm model (a) Langmuir (b) Freundlich

Table 1 The adsorption isotherm and kinetic models parameters for $\mathrm{Cu}$ and $\mathrm{Cr}$ by GPA

\begin{tabular}{|c|c|c|c|c|c|c|c|c|c|}
\hline Metal & Model & $\mathrm{Q}_{\max }$ & $B$ & $\mathrm{R}^{2}$ & $n$ & $\mathrm{k}$ & $\mathrm{k}_{1}$ & $\mathrm{Q}_{\mathrm{e}}$ & $k_{2}$ \\
\hline \multirow[t]{4}{*}{$\mathrm{Cu}$} & Langmuir & -107.53 & -0.0008 & 0.99 & & & & & \\
\hline & Freundlich & & & 0.98 & 0.67 & 0.007 & & & \\
\hline & Pseudo-first-order & & & 0.98 & & & 0.23 & 141.48 & \\
\hline & Pseudo-second-order & & & 0.99 & & & & 169.49 & 0.002 \\
\hline \multirow[t]{4}{*}{$\mathrm{Cr}$} & Langmuir & 27.78 & 0.0016 & 0.99 & & & & & \\
\hline & Freundlich & & & 0.97 & 1.69 & 0.301 & & & \\
\hline & Pseudo-first-order & & & 0.96 & & & 0.25 & 9.57 & \\
\hline & Pseudo-second-order & & & 0.99 & & & & 18.62 & 0.039 \\
\hline
\end{tabular}
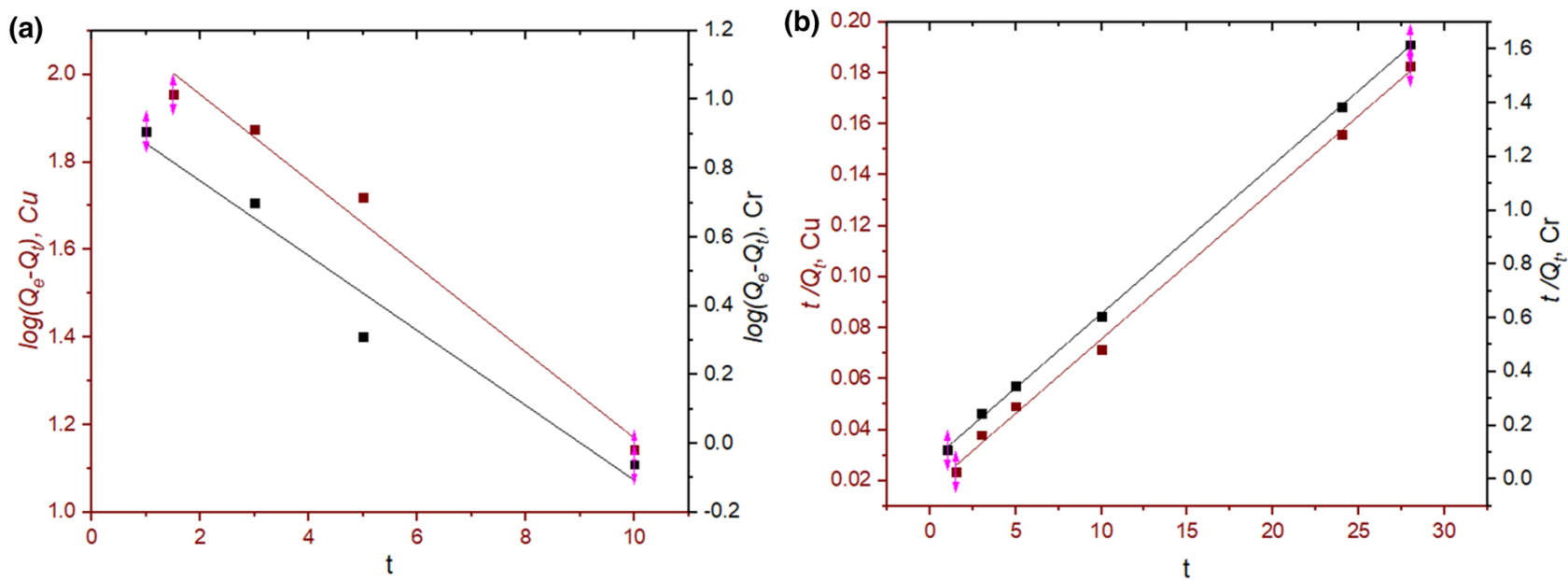

Fig. 10 Adsorption kinetic model (a) Pseudo-first order (b) Pseudo-second order

$\mathrm{Cu}(\mathrm{II}) / \mathrm{Cr}(\mathrm{VI})$ by GPA film followed the pseudo-secondorder equation. In addition, comparative study of the maximum adsorption capacity for $\mathrm{Cu}(\mathrm{II}) / \mathrm{Cr}(\mathrm{VI})$ removal in this study with previous researches have shown in Table 2 .

\subsection{Reusability of GPA}

The reusability of GPA is essential to enhance the costeffectiveness of the adsorption process for multiple 
Table 2 Adsorption capacity of different adsorbent for $\mathrm{Cu}$ (II) and $\mathrm{Cr}(\mathrm{VI})$ ion removal

\begin{tabular}{llcc}
\hline Metal & Adsorbent & \multicolumn{2}{c}{$\begin{array}{l}\text { Adsorption Capac- } \\
\text { ity (mg/g) }\end{array}$} \\
\hline Cu & Amidoximated AN grafted non-woven PE & 74.62 & {$[38]$} \\
& Itaconic acid/acrylamide graft PET fiber & 7.73 & {$[39]$} \\
& Methacrylic acid/acrylamide graft PET fiber & 31.25 & {$[40]$} \\
Multi-walled carbon nanotubes & 12.34 & {$[41]$} \\
Purified carbon nanotubes & 229.28 & {$[42]$} \\
polyhydroxylbutyrate carbon nanotubes & 229.28 & {$[42]$} \\
Sugar beet pulp carbon & 14.81 & {$[43]$} \\
GPA & 153.89 & This study \\
Magnetic nanoparticle-carbon nanotube composites & 19.65 & {$[44]$} \\
n-butylacrylate grafted chitosan & 17.14 & {$[45]$} \\
Grafted Bamboo charcoal & 17.93 & {$[46]$} \\
Chitosan-cl-poly(alginiacid)nano hydrogel & 26.49 & {$[47]$} \\
Silica gel/chitosn-g-poly(butylacrylate) & 55.71 & {$[48]$} \\
Palm trunk charcoal & 24.7 & {$[49]$} \\
Banana peels & 6.17 & {$[50]$} \\
GPA & 17.34 & This study \\
\hline
\end{tabular}

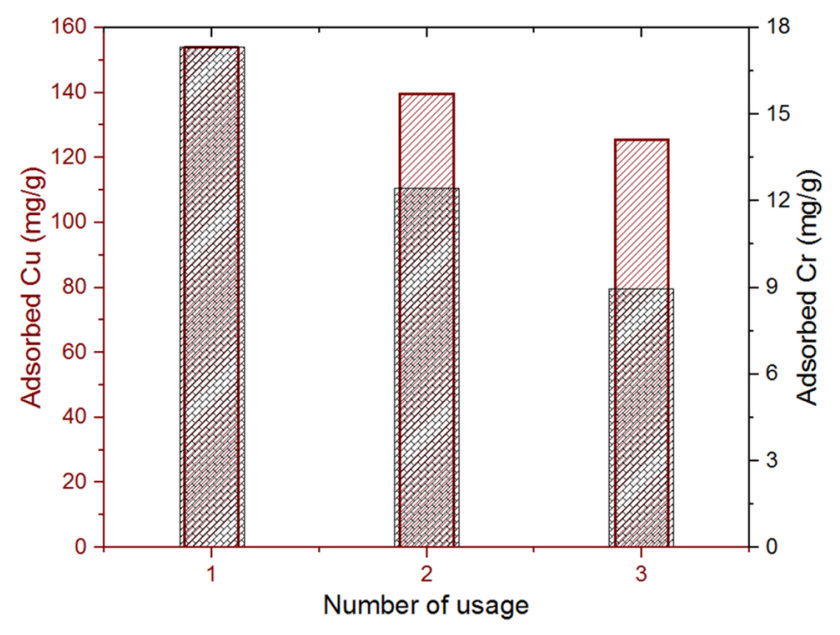

Fig. 11 Reusability of GPA

adsorption-desorption steps. The present study observed the reusability of adsorbent to remove $\mathrm{Cu}(\mathrm{II}) / \mathrm{Cr}(\mathrm{VI})$ from solution. The desorption of $\mathrm{Cu}(\mathrm{II}) / \mathrm{Cr}(\mathrm{VI})$ from the GPA films was carried out using $1 \mathrm{M} \mathrm{HCl}$ and $1 \mathrm{M} \mathrm{NaOH}$, respectively. Results indicate the acidic medium can facilitate the desorption of $\mathrm{Cu}(\mathrm{II}) / \mathrm{Cr}(\mathrm{VI})$ from GPA. After desorption, the GPA films were washed with distilled water and reused. The films showed no significant loss of activity during reuse. The repeated regeneration gradually decreased the removal capacity of $\mathrm{Cu}(\mathrm{II}) 153.89 \mathrm{mg} / \mathrm{g}$ to 125.54 and $\mathrm{Cr}(\mathrm{VI})$ 17.34 to $8.97 \mathrm{mg} / \mathrm{g}$ shown in Fig. 11. However, the reduction in adsorption capacity may be owing to the decrease in surface area and pore volume, and the relatively weak active site.

\section{Conclusions}

The grafted polymeric adsorbent (GPA) was successfully synthesized using diallyl dimethyl-ammonium chloride (DADMAC) and acrylic acid (AAc) embedded non-woven irradiated polythene sheet. The molecular interaction, surface morphology, and physical phenomena of synthetized GPA were supported by FTIR, SEM, and TGA. The results of the above analysis convey evidence of successfully made of a composite film comprising DAD$M A C$ and $A A C$ on the PE sheet. Effect of $\mathrm{pH}$, initial metal concentration, contact time, and applied temperature on adsorption capacity of $\mathrm{Cu}(\mathrm{II}) / \mathrm{Cr}(\mathrm{VI})$ were investigated batch-wise and found similar trend relating literature. The optimum conditions were $\mathrm{pH} 4.84(\mathrm{Cu})$, and $1.5(\mathrm{Cr})$, $1000 \mathrm{ppm}$ initial concentration, $24 \mathrm{~h}$ contact time to acquire maximum $\mathrm{Cu}(\mathrm{II}) / \mathrm{Cr}(\mathrm{VI})$ removal efficiency. The adsorption isotherm data fitted well with Freundlich for $\mathrm{Cu}$ and Langmuir for $\mathrm{Cr}$, implying that the models can be applied to remove $\mathrm{Cu} / \mathrm{Cr}$ by GPA. On the other hand, Pseudo-second-order kinetic model was favored than first-order owing to the best fitting with $R^{2}=0.99$ of measured data. In conclusion, the GPA can be considered as an excellent adsorbent for heavy metal removal from wastewater due to good adsorption capacity, low cost, and reusability.

\section{Compliance with ethical standards}

Conflict of interest On behalf of all authors, the corresponding author states that there is no conflict of interest. 


\section{References}

1. Meng J, Feng X, Dai Z, Liu X, Wu J, Xu J (2014) Adsorption characteristics of $\mathrm{Cu}(\mathrm{II})$ from aqueous solution onto biochar derived from swine manure. Environ Sci Pollut Res 21:7035-7046

2. Lytras G, Lytras C, Argyropoulou D, Dimopoulos N, Malavetas G, Lyberatos G (2017) A novel two-phase bioreactor for microbial hexavalent chromium removal from wastewater. J Hazard Mater 336:41-51

3. Demirbas E, Dizge N, Sulak MT, Kobya M (2009) Adsorption kinetics and equilibrium of copper from aqueous solutions using hazelnut shell activated carbon. Chem Eng J 148:480-487

4. Hosseini MS, Belador $\mathrm{F}$ (2009) $\mathrm{Cr}(\mathrm{III}) / \mathrm{Cr}(\mathrm{VI})$ speciation determination of chromium in water samples by luminescence quenching of quercetin. J Hazard Mater 165:1062-1067

5. Megharaj M, Avudainayagam S, Naidu R (2003) Toxicity of hexavalent chromium and its reduction by bacteria isolated from soil contaminated with tannery waste. Curr Microbiol 47:51-54

6. Karthik C, Barathi S, Pugazhendhi A, Ramkumar VS, Thi NBD, Arulselvi PI (2017) Evaluation of $\mathrm{Cr}(\mathrm{VI})$ reduction mechanism and removal by Cellulosimicrobium funkei strain AR8, a novel haloalkaliphilic bacterium. J Hazard Mater 333:42-53

7. Tong X, Li J, Yuan J, Xu R (2011) Adsorption of Cu(II) by biochars generated from three crop straws. Chem Eng J 172:828-834

8. Jin H, Capareda S, Chang Z, Gao J, Xu Y, Zhang J (2016) Copper(II) removal potential from aqueous solution by pyrolysis biochar derived from anaerobically digested algaedairy-manure and effect of koh activation. J Environ Chem Eng 4:365-372

9. Kandah MI, Al-Rub FAA, Al-Dabaybeh N (2003) The aqueous adsorption of copper and cadmium ions onto sheep manure. Adsorpt Sci Technol 21:501-509

10. Pellera FM, Giannis A, Kalderis D, Anastasiadou K, Stegmann $\mathrm{R}$, Wang JY, Gidarakos E (2012) Adsorption of $\mathrm{Cu}$ (II) ions from aqueous solutions on biochars prepared from agricultural byproducts. J Environ Manage 96:35-42

11. Bergmann MEH, Koparal AS (2011) Electrochemical Antimony Removal From Accumulator Acid: Results From Removal Trials in Laboratory Cells. J Hazard Mater 196:59-65

12. Wu F, Sun F, Wu S, Yan Y, Xing B (2012) Removal of antimony(III) From Aqueous Solution by Freshwater Cyanobacteria Microcystis Biomass. Chem Eng J 183:172-179

13. Olgun A, Atar N, Wang S (2013) Batch and column studies of phosphate andnitrate adsorption on waste solids containing boron impurity. Chem Eng J 222:108-119

14. Xu X, Cao X, Zhao L, Wang H, Yu H, Gao B (2013) Removal of $\mathrm{Cu}, \mathrm{Zn}$, and $\mathrm{Cd}$ from aqueous solutions by the dairy manurederived biochar. Environ Sci Pollut Res 20:358-368

15. Yang R, Li Z, Huang M, Luo N, Wen J, Zeng G (2019) Characteristics of Fulvic Acid During Coprecipitation and Adsorption to Iron Oxides-Copper Aqueous System. J Mol Liq 274:664-672

16. Naiya TK, Bhattacharya AK, Das SK (2009) Adsorption of Cd(II) and $\mathrm{Pb}$ (II) From Aqueous Solutions On Activated Alumina. J Colloid Interface Sci 333:14-26

17. Tang C, Liu Z, Peng C, Chai L (2019) New Insights Into the Interaction Between Heavy Metals and Struvite: Struvite as Platform for Heterogeneous Nucleation of Heavy Metal Hydroxide. Chem Eng J 365:60-69

18. Nakashima S, Sturgeon RE, Willie SN, Berman SS (1988) Determination of Trace Elements in Sea Water by Graphite-Furnace Atomic Absorption Spectrometry After Preconcentration by Tetrahydroborate Reductive Precipitation. Anal Chim Acta 207:291-299

19. Mendil D, Bardak H, Tuzen M, Soylak M (2013) Selective Speciation of Inorganic Antimony On Tetraethylenepentamine
Bonded Silica Gel Column and its Determination by Graphite Furnace Atomic Absorption Spectrometry. Talanta 107:162-166

20. Marina Šćiban BŠ, Klašnja M (2006) Modified softwood sawdust as adsorbent of heavy metal ions from water. J Hazard Mater 136:266-271

21. Makhadoa E, Pandeya S, Ramontjaa J (2019) Microwaveassisted green synthesis of xanthan gum grafted diethylamino ethyl methacrylate: An efficient adsorption of hexavalent chromium. Carbohydr Polym 222:114989

22. Zhou X, Wang J, Nie J, Du B (2016) Poly(Nisopropylacrylamide)-based ionic hydrogels: synthesis, swelling properties, interfacial adsorption and release of dyes. Polym J 48:431-438

23. Alam MJ, Das BC, Rahman MW, Biswas BK, Khan MMR (2015) Removal of dark blue-GL from wastewater using water hyacinth: a study of equilibrium adsorption isotherm. DESALIN WATER TREAT 56:1520-1525

24. Rahman MW, Ali MY, Saha I, Raihan MA, Moniruzzaman M, Alam MJ, Deb A, Khan MMR (2017) Date palm fiber as a potential lowcost adsorbent to uptake chromium (VI) from industrial wastewater. DESALIN WATER TREAT 88:169-178

25. Parvin S, Rahman MW, Saha I, Alam MJ, Khan MMR (2019) Coconut tree bark as a potential low-cost adsorbent for the removal of methylene blue from wastewater. DESALIN WATER TREAT 146:385-392

26. Ali MY, Rahman MW, Moniruzzaman M, Alam MJ, Saha I, Halim MA, Deb A, Sumi MSA, Parvin S, Haque MA, Khan MMR, Khan M (2016) Nypa fruticans as a potential low cost adsorbent to uptake heavy metals from industrial wastewater. IJABER 14:1359-1371

27. Moniruzzaman M, Kader S, Alam MJ, Aktar S, Deb A, Khan M (2019) Utilization of Waste Cigarette Buds for the Removal of Reactive Dye from Wastewater. j. eng. res. appl. 9:2248-9622

28. Sathish T, Vinithkumar NV, Dharani G, Kirubagaran R (2015) Efcacy of mangrove leaf powder for bioremediation of chromium(VI) from aqueous solutions: kinetic and thermodynamic evaluation. Appl Water Sci 5:153-160

29. Yeasmin MS, Mondal MdIH (2015) Synthesis of highly substituted carboxymethyl cellulose depending on cellulose particle size. Int J Biol Macromol 80:725-731

30. Nuri Ünlü ME (2006) Adsorption characteristics of heavy metal ions onto a low cost biopolymeric sorbent from aqueous solutions. J Hazard Mater 136:272-280

31. Schmuhl R, Krieg HM, Keizer K (2001) Adsorption of $\mathrm{Cu}(\mathrm{II})$ and $\mathrm{Cr}(\mathrm{VI})$ ions by chitosan: Kinetics and equilibrium studies. Water SA 27:1-7

32. Ho YS, Ng JCY, Mckay G (2017) Removal of Lead ( Ii ) From Effluents By Sorption on Peat Using Second-Order Kinetics Removal of Lead ( II ) From Effluents. Sep Sci Technol 36:241-261

33. Shukla SR, Skhardande VD (1992) Column studies on metal ion removal by dyed cellulosic materials. J appl polym Sci 44:903-910

34. Ali AEH (2005) Radiation synthesis of interpolymer polyelectrolyte complex and its application as a carrier for colon-specific drug delivery system. Biomaterials 26:2733-2739

35. Kwak SH, Kwon SR, Baek S, Lim SM, Joo YC, Chung TD (2016) Densely charged polyelectrolyte-stuffed nanochannel arrays for power generation from salinity gradient. Sci Rep 6:26416

36. Pirgalıoglu S, Özbelge TA, Özbelge HO, Bicak N (2015) Crosslinked polyDADMAC gels as highly selective and reusable arsenate binding materials. Chem Eng J 262:607-615

37. Yue R, Chen Q, Li S, Zhang X, Huang Y, Feng P (2018) One-step synthesis of 1,6-hexanediamine modified magnetic chitosan microspheres for fast and efficient removal of toxic hexavalent chromium. Sci Rep 8:11024 
38. Rahman N, Hossen MS, Miah AR, Marjub MM, Dafader NC, Shahnaz S, Alam MF (2019) Removal of $\mathrm{Cu}(\mathrm{II}), \mathrm{Pb}(\mathrm{II})$ and $\mathrm{Cr}(\mathrm{VI})$ ions from aqueous solution using amidoximated non-woven polyethylene-g-acrylonitrile fabric. J Environ Health Sci Eng $4: 1-17$

39. Coşkun R, Soykan C, Saçak M (2006) Removal of some heavy metal ions from aqueous solution by adsorption using poly(ethylene terephthalate)-g-itaconic acid/acrylamide fiber. React Funct Polym 66:599-608

40. Coşkun R, Soykan C, Saçak M (2006) Adsorption of copper(II), nickel(II) and cobalt(II) ions from aqueous solution by methacrylic acid/ acrylamide monomer mixture grafted poly(ethylene terephthalate) fiber. Sep Purif Technol 49:107-114

41. Mobasherpour I, Salahiand E, Ebrahimi M (2014) Thermodynamics and kinetics of adsorption of $\mathrm{cu}$ (II) from aqueous solutions onto multi-walled carbon nanotubes. J Saudi Chem Soc 18:792-801

42. Bankole MT, Abdulkareem AS, Mohammed IA, Ochigbo SS, Tijani JO, Abubakre OK, Roos WD (2018) Selected Heavy Metals Removal From electroplating Wastewater by Purified and Polyhydroxylbutyrate Functionalized Carbon Nanotubes Adsorbents. Sci Rep 9:4475

43. Ozer A, Tumen $F(2005) \mathrm{Cu}(\mathrm{II})$ adsorption from aqueous solutions on sugar beet pulp carbon. Eur J miner process Environl prot 5:26-32

44. Lu W, Li J, Sheng Y, Zhang X, You J, Chen L (2017) One-pot synthesis of magnetic iron oxide nanoparticle-multiwalled carbon nanotube composites for enhanced removal of $\mathrm{Cr}(\mathrm{VI})$ from aqueous solution. J Colloid Interface Sci 505:1134-1146
45. Kumar ASK, Kumar CU, Rajesh V, Rajesh N (2014) Microwave assisted preparation of $n$-butyl acrylate grafted chitosan and its application for $\mathrm{Cr}(\mathrm{VI})$ adsorption. Int J Biol Macromol 66:135-143

46. Wu Y, Ming Z, Yang S, Fan Y, Fang P, Sha H, Cha L (2017) Adsorption of hexavalent chromium onto Bamboo Charcoal grafted by $\mathrm{Cu} 2+-\mathrm{N}$-aminopropylsilane complexes: Optimization, kinetic, and isotherm studies. J Indust Eng Chem 46:222-233

47. Sharma G, Naushad M, Al-Muhtaseb AH, Kumar A, Khan MR, Kalia S, Shweta BM, Sharma A (2017) Fabrication and characterization of chitosan-crosslinked-poly(alginicacid) nanohydrogel for adsorptive removal of $\mathrm{Cr}(\mathrm{VI})$ metal ion fromaqueous medium. Int J Biol Macromol 95:484-493

48. Nithya R, Gomathi T, Sudha PN, Venkatesan J, Anil S, Kim S (2016) Removal of $\mathrm{Cr}(\mathrm{VI})$ from aqueous solution using chitosan-gpoly(butyl acrylate)/silica gel nanocomposite. Int J Biol Macromol 87:545-554

49. Yadav SK, Dixit AK (2016) Efficient removal of $\mathrm{Cr}(\mathrm{VI})$ from aqueous solution onto palm trunk charcoal: kinetic and equilibrium studies. J Chem Sci 7:1-7

50. Ali A, Saeed K, Mabood F (2016) Removal of chromium (VI)from aqueous medium using chemically modified banana peels as efficient low-cost adsorbent. Alexandria Eng J 55:2933-2942

Publisher's Note Springer Nature remains neutral with regard to jurisdictional claims in published maps and institutional affiliations. 